\title{
Novel strategies for the site-specific covalent labelling of nucleic acids
}

\author{
Samuel H. Weisbrod and Andreas Marx*
}

To broaden the scope of applications in DNA nano- and biotechnology, material science, diagnostics and molecular recognition the functionalization of DNA is of utmost importance. In the last decade many new methods have been developed to achieve this goal. Apart from the direct chemical synthesis of modified DNA by automated phosphoramidite chemistry incorporation of labelled triphosphates and the post-synthetic labelling approach evolved as valuable methods. New bioorthogonal reactions as Diels-Alder, click and Staudinger ligations pushed forward the post-synthetic approach as new insights into DNA polymerase substrate specifity allowed generation and amplification of labelled DNA strands. These novel developments are summarized herein.

\section{Introduction}

For quite some time investigation and manipulation of DNA have not only been restricted to the field of genetics but also utilized for many different applications apart from its natural destination. ${ }^{1}$ Watson-Crick base pairing is specific and easily predictable, thus forming geometrically well-defined duplex structures from complementary strands. The same properties that allow efficient storage and replication of the genetic code facilitate the self-assembly of simple oligodeoxynucleotides (ODNs). This basic principle has been used for the construction of two- and three-dimensional nanostructures ${ }^{2}$ and is the basis for ODN markers in many diagnostic applications ${ }^{3}$ as well as DNA mediated reactions or catalysts. ${ }^{4}$

In any case the functionalization of the DNA is of capital importance. In nanotechnology the DNA scaffold has to be

Department of Chemistry and Konstanz Research School Chemical Biology, University of Konstanz, 78457 Konstanz, Germany. E-mail: Andreas.Marx@uni-konstanz.de; Fax: + 49753188 5140; Tel: + 497531885139

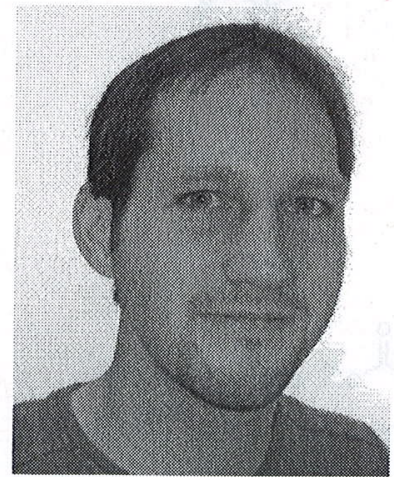

Samuel H. Weisbrod
Born in 1980 in Donaueschingen (Germany), Samuel $H$. Weisbrod studied chemistry at the University of Konstanz, Germany. In 2004 he had a six month industrial placement at BASF, Ludwigshafen, Germany, before he finished his study in Konstanz with his diploma thesis in 2006 in the group of Prof. A. Marx. Since then he has been working as a graduate student on the topic of oligonucleotide conjugation by Staudinger ligation.

equipped with functional molecules that provide e.g. new electrical, ${ }^{5,6}$ magnetic ${ }^{5,7}$ or light transporting properties ${ }^{8}$ for the construction of nanowires or proteins for artificial multienzymes. ${ }^{9}$ For diagnostic applications conjugation of DNA to fluorescent dyes, ${ }^{10}$ affinity tags like biotin or antibodies, proteins, carbohydrates ${ }^{11}$ and chip surfaces ${ }^{12}$ is needed, whereas for DNA programmed synthesis reactants or catalysts have to be bound to DNA. ${ }^{13}$ In search of highly specific aptamers or DNA based catalysts ${ }^{14,15}$ the extension of DNA binding properties beyond simple $\mathrm{H}$-bonding capabilities and polyanionic character is highly desirable.

Short highly modified DNA strands are accessible by solidphase synthesis. If the incorporation of the label can be accomplished within the synthesizer cycle, fewer steps and only a single purification are required. Chemical incompatibility with synthesis conditions, the limited selection of readily available phosphoramidites and possible limitations of the stepwise yield after incorporation of the modification are narrowing the scope of these methods. In general, postsynthetic approaches can overcome these limitations and allow

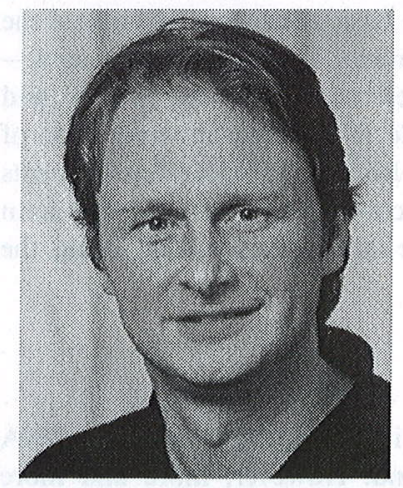

Andreas Marx
Andreas Marx studied chemistry in Freiburg (Germany), Sussex (UK), and Bochum (Germany). In 1997 he earned his DPhil at Basel University (Switzerland). After a postdoctoral time at Nagoya University (Japan) he began his independent career at the Kekulé-Institut für Organische Chemie und Biochemie at the University of Bonn (Germany) 1999. In 2004 he moved to the University of Konstanz (Germany) as a full-professor in chemistry and currently holds the Chair of Organic Chemistry and Cellular Chemistry. His research focuses on the chemical biology of DNA replication processes. 
flexible conjugation of different functional molecules to the same modified ODN. Here a small modification is introduced first during ODN synthesis and the labels are then conjugated to the modified ODN by a chemoselective reaction with the introduced specific functionality after ODN synthesis post-synthetically.

A standard procedure therefore is the usage of alkylamine modified ODNs for conjugation with electrophilic derivatives of the molecular labels, which are both readily available. However, this method suffers from low chemoselectivity as cross reactivity with the amino groups of the bases and reagent hydrolysis in water, which can be only reasonably balanced by the $\mathrm{pH}$ of the buffer solution. Another problem arises out of the wish for chemically more complicated labels, where the labels themselves have to be protected against the coupling reaction. So ideally the coupling reaction has to be sitespecific, bioorthogonal, high yielding and for in vivo experiments biocompatible and nontoxic. No standard conjugation protocol fulfils all of these conditions so far, but a plethora of promising methods has recently been developed to serve the different needs.

However, the construction of long DNA strands functionalized at high density is a difficult task, which cannot be accomplished efficiently by chemical DNA synthesis. In contrast DNA polymerases can synthesize DNA strands several thousand base pairs long and have been utilized in polymerase chain reactions (PCR). Unfortunately, their acceptance of unnatural nucleoside triphosphate analogues carrying the desired functional labels is restricted and frequently not predictable. Here also the post-synthetic approach can help with small functionalities that will be accepted by DNA polymerases in a more predictable manner. For the subsequent multi-labelling high-yielding but bioorthogonal coupling reactions are desired, because the fully labelled products are often difficult to purify from incompletely labelled constructs.

While excellent reviews on DNA conjugation were published some time ago, ${ }^{16}$ recent reviews cover the synthesis of modified ODNs with fundamental altered sugar moiety or bases. ${ }^{17}$ In this review we shed light on newly developed labelling approaches in which the functional label is attached to the ODN altering the behaviour of the DNA as little as possible. Therefore, first some basic considerations about the positioning of the label are made. The different conceptsincorporation by DNA synthesizers $v s$. enzymes (Fig. 1) and post-synthetic approach (Table 1) $v$ s. direct incorporation of labels - will then be discussed. Because of recent developments in the field of bioorthogonal conjugation reactions the main focus is on the post-synthetic labelling approach, being the most flexible method so far.

\section{Basic considerations}

In case of simple applications it is sufficient to label the DNA by linkage at the $5^{\prime}$ or $3^{\prime}$ end. However, more and more applications call for DNA where complicated functional molecules have to be attached site-specifically at positions within the strand. In principle, chemical modifications can be introduced into ODNs at the nucleobases, the ribose unit or the backbone level.
A<smiles></smiles><smiles>[R]c1nc2c(N)ncnc2n1[C@H]1O[C@H](CN2CC2)[C@@H](O)[C@@H](O)[C@H]1O</smiles>

or

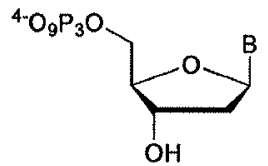

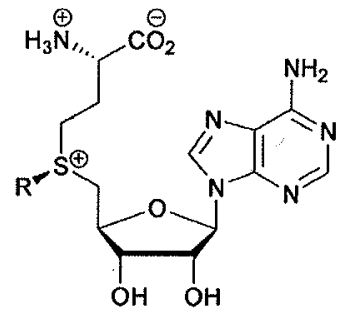

Fig. 1 Building blocks for modified DNA synthesis (A) phosphoramidites for solid phase DNA synthesis (B) triphosphates for DNA polymerases (C) S-adenosyl-L-methionine analogues for methyltransferases.

Table 1 Post-synthetic labelling reactions performed on DNA

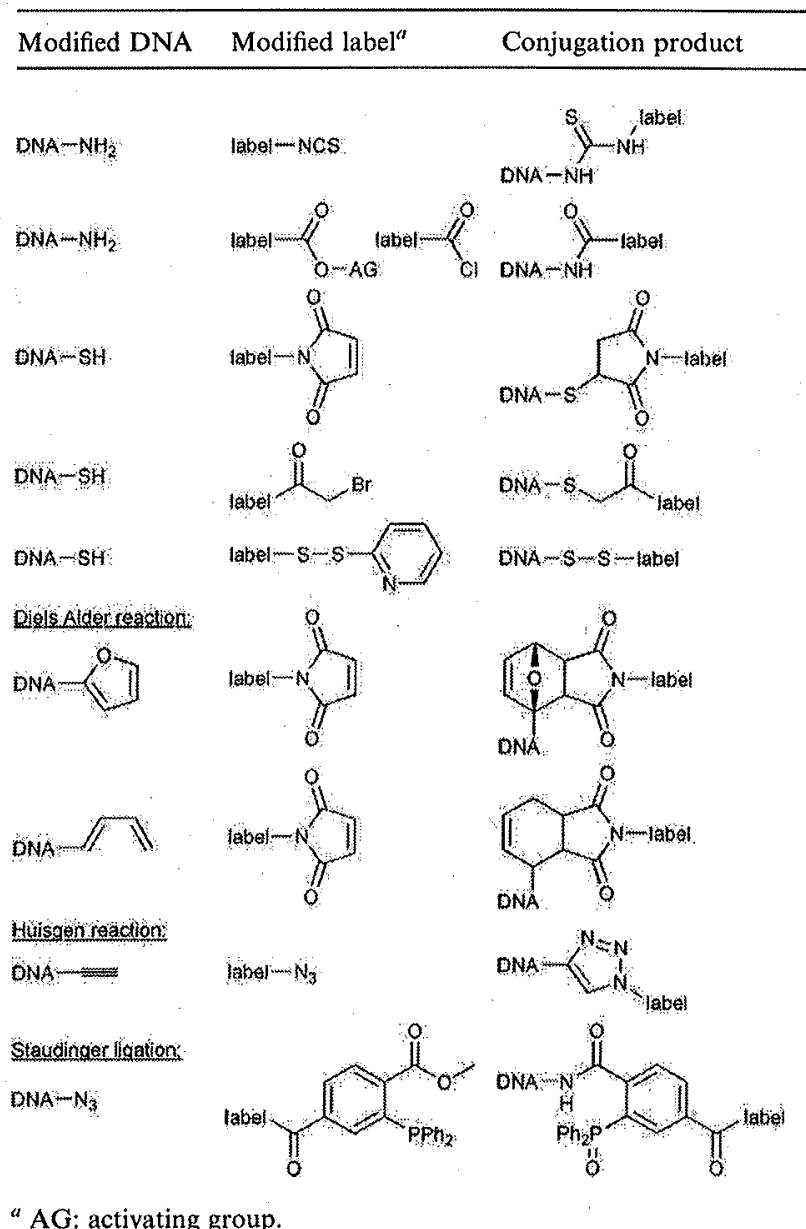

"AG: activating group.

Many examples have been published, where the functional molecule replaces one or more nucleotides and therefore is 


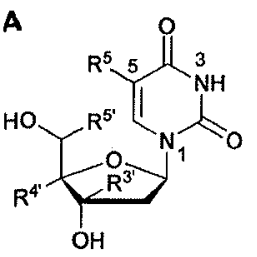

pyrimidine numbering
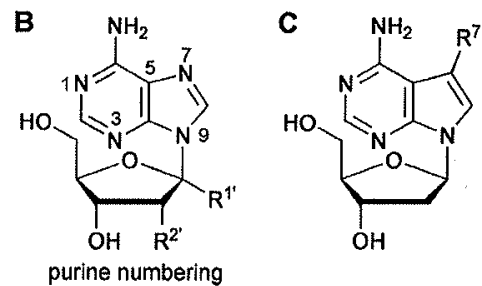

Fig. 2 Different imaginable labelling positions for internal labelling, (A) Thymidine analogue with $3^{\prime}, 4^{\prime}$ or $5^{\prime}$ labelling or base labelling $\left(\mathrm{R}^{5}\right)$. (B) Adenosine analogue with $1^{\prime}$ or $2^{\prime}$ labelling $\left(\mathrm{R}^{2}\right.$, usually $\left.\mathrm{OR}\right)$. (C) 7-Deaza $2^{\prime}$-deoxyadenosine with base labelling $\left(R^{7}\right)$.

inserted in between the backbone. ${ }^{16,18}$ Albeit sufficient for some applications this approach will not be further discussed since pertubation of helix conformation and incompatibility with most enzymatic reactions are limitations of this approach.

Investigations in the last few years indicate suitable positions for the attachment of modifications within the ribose moiety (Fig. 2). Modifications at $3^{\prime}, 4^{\prime}$ and $5^{\prime}$ positions are near the polymerisation reaction sites and often diminish coupling yields. ${ }^{16} 1^{\prime}$ modifications direct into the minor groove and interfere with base pairing and thus have also been rarely used. ${ }^{16,19}$ Ribose modification at $2^{\prime}$ is synthetically simplest starting with ribose instead of deoxyribose, so this modification is more common for labelling DNA. Depending on the nature of the linker and the label in most cases the resulting DNA duplex is destabilized. Thereby aromatic labels have an stabilizing effect probably due to groove interactions or $\pi$-stacking. These positions allow labelling of ODNs only by chemical synthesis because DNA polymerases, the enzymes that synthesize DNA enzymatically, are inefficient in processing sugar modified analogues.

The Watson-Crick face of the nucleobase, which is responsible for the interstrand base pairing, should not be touched for modifications. However, the bases have proved to be best suited for labelling purposes, especially for labelled deoxyribonucleotide triphospate (dNTP) analogues, which often are accepted as substrates for DNA polymerases. Modifications of the pyrimidines at the 5-position fit well into the major groove and are often used. Modifications at C- 8 of purines are not accommodated well into the major groove and disturb at least DNA polymerases by incorporation of such nucleotide analogues. ${ }^{15,20,21}$ More elaborated are C-7 modified 7-deazapurine analogues, where the modification points towards the major groove $^{22}$ which is somehow a prerequisite for efficient processing of modified triphosphates by DNA polymerases. ${ }^{15,21}$

\section{Chemical synthesis of functionalized DNA}

Since DNA synthesizers evolved to standard equipment, not only the production of relative large quantities of nonmodified DNA is feasible but also the generation of chemical modified DNA. Many variations of protecting groups and synthesis conditions allow the incorporation of a broad range of modifications. ${ }^{16}$ The most straight-forward way is labelling after DNA synthesis at the $5^{\prime}$ end and is most often used for attaching dyes for diagnostic applications. Some recent examples include phosphoramidite reagents for the attachment of fluorescein, ${ }^{23}$ tetramethyl rhodamine ${ }^{24}$ and cyanine dyes. ${ }^{25}$ For the sensitive identification of oligonucleotides by mass spectrometry mass tags have been recently invented as $5^{\prime}$ labels. ${ }^{26}$ But also modifiers for the $3^{\prime}$ end as modified solid support have been developed and a range of fluorescent dyes, quenchers and affinity tags like biotin are commercially available. Widely used in real-time PCR and other diagnostic applications are both $5^{\prime}$ and $3^{\prime}$ labelled probes. Here $5^{\prime}$ fluorophore $3^{\prime}$ quencher setup is most common using commercially available black hole quenchers for the construction of molecular beacons. ${ }^{27}$

As already mentioned a common position for attaching labels internally to an ODN by phosphoramidites is the $2^{\prime}$ position. Pyrenes have been attached to the $2^{\prime}$ oxygen by one methylene group linkage for labelling DNA ${ }^{28}$ and RNA. ${ }^{28,29}$ The resulting oligonucleotides can distinguish between DNA and RNA hybridization by fluorescence. Another linker strategy makes use of the carbamate moiety as linker. Several labels have been attached ${ }^{30}$ and dansyl ${ }^{31}$ and pyrene ${ }^{32}$ derivatives have been further investigated. The labels can be directed into the major groove at this position by using the arabino epimer of the phosphoramidites. This has been done using carbamate linked pyrene labels. ${ }^{33} 2^{\prime}$-Amino derivatives have also been used for attaching labels to ODNs at the $2^{\prime}$ position. ${ }^{34}$ Several aromatic residues ${ }^{35,36}$ have been attached via carboxylic acids and incorporated as phosphoramidites. In all cases of $2^{\prime}$ labelling the resulting duplexes are thermally destabilized except rarely for aromatic labels which can compensate the steric demand by stacking with the bases.

A way to circumvent $2^{\prime}$ labels disturbing duplex formation is the use of locked nucleic acids (LNA). Here the ribose conformation is locked with an additional ring closure from $2^{\prime}-\mathrm{OH}$ to $4^{\prime}$ by a methylene group as bridge, which leads to increased thermal stability of duplexes and drives the duplex into A-DNA conformation. ${ }^{37}$ LNA monomers placed next to $2^{\prime}$-amino labeled nucleotides can thus increase thermal stability of resulting modified oligonucleotide duplexes again. ${ }^{38}$ Moreover combination of both in one monomer building block by replacing the $2^{\prime}$ oxygen in LNA by nitrogen leads to LNA that can be functionalized at the $2^{\prime}$ amino function and yet gives rise to more stable duplexes. ${ }^{39}$

The other possibility for labelling ODNs internally is attaching the label to the base. For the pyrimidine derivatives the 5 position is commonly used, purines can be labelled using either the 7 or 8 position, if phosphoramidite chemistry should be applied. Depending on the label the conformation and thermal stability of the resulting modified ODN duplex is comparable to the non-modified one. Some impressive recent examples are the synthesis of glycosylated ${ }^{40}$ ODNs and the development of various dye labelled phosphoramidites. ${ }^{41,42}$

!Obviously, the scope of modifications is limited by the compatibility of the modifications with the synthesis conditions. Additionally, in certain cases standard phosphoramidites are rapidly oxidized which can be circumvented partially by using $\mathrm{H}$-phosphonates based approaches ${ }^{36}$ which suffer e.g. from longer coupling times.

However, stable modified phosphoramidites enable a one step labelling approach and the ease of subsequent purification 
are major advantages. Multi-labelling or the generation of long DNA strands is difficult due to limitations of the coupling yield but, nevertheless, has been achieved e.g. for adjacent incorporation of 11 porphyrine labelled phosphoramidites. ${ }^{42}$

Another approach for the introduction of labels harbours the introduction of a functional group during solid phase DNA synthesis by phosphoramidites and subsequent coupling of the label on the solid support. This approach combines the modularity of the post-synthetic labelling by avoiding complicated purification steps with the advantages of organic chemistry on solid support using protected ODNs and standard organic chemistry reaction conditions. Compared to standard amino post-synthetic derivatization, higher yields can be generated with the coupling on solid support due to water-free conditions and protected exocyclic amino groups of the bases. This has been used for end ${ }^{43}$ as well as intrastrand single monomer labelling at the 5 position of the base or $2^{\prime}$-amine of the ribose generating a free amino group after photolysis of the masking photo-cleavable protecting group. ${ }^{44}$ Two different functional moieties (5-methoxycarbonylmethyl and 5-cyanomethoxycarbonylmethyl modified uridine) have been successively addressed on solid support by different amino labels (tyramin and tris(2-aminoethyl)amine) yielding twice amide linked labelled DNA. ${ }^{45}$

Another approach uses the Sonogashira cross coupling reaction between alkyne modified labels and 5-iodo-2'deoxyuridine introduced via solid phase synthesis for the introduction of protected amines, biotin or ruthenium bipyridyl complexes, ${ }^{46}$ pyrene ${ }^{47}$ or nitroxid spinlabels ${ }^{48 a}$ with excellent coupling yields (Scheme 1). However, in the latter
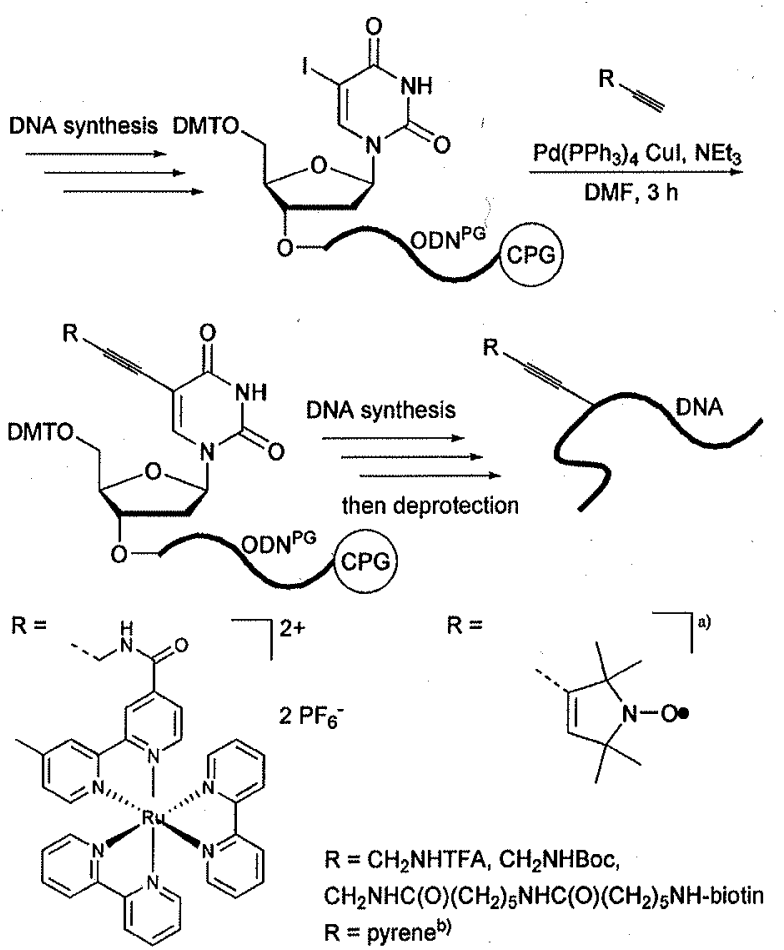

Scheme 1 Labelling on solid support. ${ }^{46}$ (a) Slightly different reaction conditions were used. ${ }^{48}$ (b) ${ }^{47}$ DMT: dimethoxytrityl; CPG: controlled pore glass, $O D N^{P G}$ : protected ODN. case low coupling yields for the proceeding DNA synthesis after introduction of the nitroxides were reported. Interestingly, a recently published approach describes the enzymatic synthesis of multiple spin-labelled DNA. ${ }^{48 b}$ In another case the DNA synthesis has been finished on the solid support before in a combinatorial approach 22 different alkynes (mainly alkyl residues, alcohols, aromatic residues, steroids) have been coupled by the Sonogashira cross coupling reaction to an intrastrand located 5-iodo-2'-deoxyuridine with good yields. ${ }^{49}$ More recently ethinyl cyanine dyes (Cy3 and Cy5) have been coupled to the $5^{\prime}$ end using the same method. ${ }^{50}$

Bromopropoxymethyl attached via the $2^{\prime}$ hydroxy-function of ribose moieties as reactive alkylbromide anchor was also used for coupling first with mercaptoacidic acid and further derivatization with amines with overall coupling efficiency between 55 and $75 \%$. ${ }^{51}$

\section{Enzymatic synthesis of functionalized DNA}

One of the advantages of using DNA for construction of artificial structures is that many enzymes modifying DNA are known. Ligases, kinases, and restriction endonucleases can be used for further processing and DNA polymerases for the construction of multi-labelled DNA. By using nucleotide analogues DNA polymerases can incorporate modifications into DNA or even amplify DNA in a PCR reaction. For the acceptance of modified triphosphates by the DNA polymerase the position of the label is important. As mentioned before modifications at $\mathrm{C} 5$ of pyrimidines and $\mathrm{C} 7$ of 7-deazapurines are often tolerated, whereas suitable modifications at $\mathrm{C} 8$ of purines are only rarely known. Only one example is known, where an imidazolyl moiety at $\mathrm{C} 8$ of $2^{\prime}$-deoxyadenosine was successfully used in a $\mathrm{PCR}$ reaction. ${ }^{52}$

Incorporation of one or even multiple consecutive nucleotide analogues is possible for a broad range of modifications in primer extension reactions. ${ }^{15,53}$ More challenging is the use of these analogues in PCR reactions, where the nucleotide analogues get incorporated and serve as a template at the same time for the generation of large amounts of modified DNA. Sometimes full replacement of the natural triphosphate is not possible. By mixing natural and labelled triphosphate the PCR though yields the desired length of product, which however is not completely labelled. This approach has been used first for labelling of PCR products with biotin (biotin-dCTP) or digoxigenin (DIG-dUTP) ${ }^{54}$ as well as for fluorescence labelling by 7-deaza-2'-deoxyadenosine labelled with trans-stilbene (Fig. $3: 1$ ) ${ }^{21}$ In the latter example the ratio between natural and unnatural triphosphate could be increased up to $3: 2$ resulting in approximately $3 \%$ of the bases getting labelled. But with higher ratios no more PCR product was observed.

More impressive are examples where the nucleotide analogue completely replaces its natural counterpart and allows defined programmed labelling of all bases of a type. The first example with systematic investigations is described by Sakthivel and Barbas. ${ }^{55}$ They had to discover that the acceptance of the nucleotide analogues heavily depends on the structure of the label and the linker (Fig. 3: examples 2-4). Also four different DNA polymerases were tested, whereas rTh DNA polymerase from Thermus thermophilus showed best 

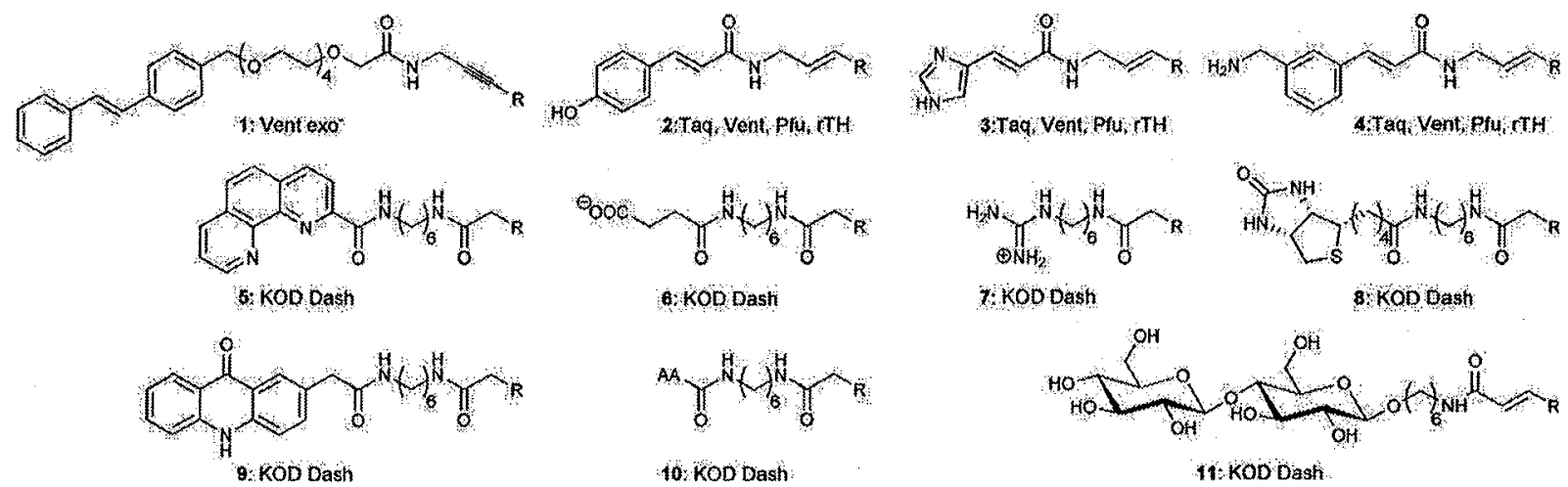

Fig. 3 Overview about successful usage of different labelled triphosphates in PCR. The employed DNA polymerases are indicated. Aside from 1 all labelled triphosphates were applied without their natural counterpart. R: 5 -substituted $2^{\prime}$-deoxyuridine-5'-triphosphate or 7 substituted 7-deaza-2'-deoxyadenosine-5'-triphosphate. AA: amino acid: Arg, Gln, His, Leu, Lys, Phe, Pro, Ser, O-Bn-Ser, Thr, Trp, Asp, Glu, Cys. 1, ${ }^{21} 2-4,{ }^{55}$ $5-8,{ }^{58} 9,{ }^{61} 10,{ }^{59} 11.60$

results. In general, family B DNA polymerases have been found to have a broader substrate spectrum with best candidates such as Vent (exo-), Pwo and KOD Dash DNA polymerases. ${ }^{15,21,55,56}$ Family A polymerases like Taq and TTh DNA polymerases appear to be less suited for the incorporation and amplification of modified substrates.

Another systematic study about linker rigidity revealed that analogues with alkyne and $E$-alkene linker were incorporated by Taq DNA polymerase, while analogues labelled by alkane and $Z$-alkene linkers were not. ${ }^{57}$ More recently Sawai $e t a l$. investigated the incorporation dependencies mainly of amines conjugated with different linkers to the base. ${ }^{56}$ Five DNA polymerases were used as well as 13 different thymidine analogues and their $2^{\prime}$-deoxycytosine counterparts. Unfortunately it is difficult to find clear trends but some suggestions can be made. Free amines near the base were not incorporated well; the positive charged amine is only accepted, if a long linker separates it from the base. The acceptance depends also on the nucleotide. For the thymidine analogues short rigid linkers as alkenes and alkynes without positive charge were better accepted than for the $2^{\prime}$-deoxycytosine counterparts, on the other hand 2-oxoethyl linkers were better accepted for the cytosine analogues than for the thymidine counterparts. In general, modifications with a possible strong impact on the active site of the DNA polymerase as positively, negatively charged or bulky groups are best accepted with long flexible linker arms (Fig. 3: examples 5-8). ${ }^{58}$ Interestingly modifications attached by thiourea linkage on long linkers are poor substrates for DNA polymerases. ${ }^{58}$ More illustrative examples of one modified dNTP analogue are the successful incorporation and amplification of several different amino acid, ${ }^{59}$ maltose and lactose ${ }^{60}$ and acridone ${ }^{61}$ labelled thymidine analogues by KOD Dash DNA polymerase in PCR reactions (Fig. 3: 9-11).

For several applications like the generation of efficient aptamers, DNA catalysts, or new sequencing approaches high density functionalization of every base might be essential. More than one substitution of natural triphosphates has been achieved several times. ${ }^{20,52,57}$ Replacement of all natural dNTPs has been published recently by Famulok et al. ${ }^{15}$ One problem they encountered was unsuccessful melting of the duplex strands during PCR under standard conditions. ${ }^{62}$ As they state, this might derive from the use of nucleobasealkynylated nucleoside triphosphates which are known to increase the melting temperature of resulting duplex DNA strands. Additionally, modification-induced formation of stable secondary structures was envisioned. ${ }^{22,63}$ After combinatorial testing of up to five additives the combination of DMSO, formamide, betaine and tetramethylammonium chloride showed the best results for PCR product formation of DNA that constitutes entirely of modified building blocks. ${ }^{62}$ Additionally, the melting temperature during the PCR program was also increased to $99^{\circ} \mathrm{C}$ requiring the use of exceptionally thermostable Pwo DNA polymerase. ${ }^{15}$

\section{Post-synthetic functionalization}

\section{General remarks}

Common problems of DNA conjugation via suitably modified phosphoramidites or triphosphates are low synthesis yields and hampered enzymatic incorporation or amplification due to incompatibility between the additional functional groups and synthesizer chemistry or enzyme catalysis. Through first introducing short reactive groups by either chemical or enzymatic DNA synthesis and subsequent post-synthetic further functionalisation with the desired label several problems for the generation of modified DNA can be circumvented. The challenge is here to find reactive groups and corresponding specific reactions for complete site-specific and chemoselective labelling under mild conditions. The idea is as old as the generation of chemical modified DNA itself using amines with reactive electrophiles such as active esters, thiocyanates or acid chlorides. Although plenty of modifications are commercially available, the scope is limited and the method suffers from conditions that interfere with most post-synthetic DNA labelling approaches.

In general, the reaction has to proceed in water using relatively low concentrations of reactants, with high chemoselectivity and under mild conditions and thereby give rise for high yields especially in multi-label reactions. In the last few years new bioorthogonal reactions have been reinvented or 
evolved so that they can be used for this special purpose leading to many new promising approaches and methods in this field.

Beside amines, which are conventionally used, thiol groups can be reacted with different moieties such as $\alpha$-haloacetyls, ${ }^{64}$ maleinimides ${ }^{65}$ or activated disulfides. ${ }^{66}$ Also the strong binding to gold can be utilized to label gold nanoparticles with DNA or bind thiolated DNA to gold surfaces. ${ }^{67}$ One drawback with thiols is the necessary disulfide reduction prior to the bioconjugation reaction. Nevertheless the amine and thiol based approaches are for many applications sufficient due to their commercial availability.

However, one particularly interesting example using a 5-(methoxy-carbonylmethyl)-2'-deoxyuridine $5{ }^{\prime}$-triphosphate has been published recently. ${ }^{68}$ Several DNA polymerases (Vent(exo-), KOD Dash and $P w o$ ) were capable of incorporating this triphosphate in a PCR reaction using a $108 \mathrm{bp}$ long template. Subsequent ion exchange of sodium against triethylammonium by ion exchange resin rendered the modified DNA soluble in dry DMF for the subsequent amidation with different amines. This example circumvents aqueous reaction conditions for the post-synthetic labelling step. Maybe this can be used to expand the scope of possible labelling reactions to reactions that cannot be performed in water. In the following we highlight some recently developed post-synthetic approaches for efficient DNA conjugation.

\section{Diels-Alder reaction}

The Diels-Alder $[4+2]$ cycloaddition ${ }^{69}$ between a diene and a dienophile is a useful carbon-carbon bond-forming reaction which can be performed under mild conditions. The specific reactivity between both functionalities and the acceleration of the reaction in aqueous solvents ${ }^{70}$ make it suitable for covalent bioconjugation, ${ }^{71}$ although in principle the reaction is reversible. Another advantage is the commercial availability of maleimide functionalized labels in which the maleimide can be used as dienophile.

Indeed, the reaction has been used for bioconjugation of nucleic acids. First conjugations with RNA showed the principal usability for bioconjugation with nucleic acids resulting in RNA catalysts for the Diels-Alder cycloaddition. ${ }^{73}$ For post-synthetic $5^{\prime}$ end labelling of DNA cyclohexadiene and acyclic hexadiene phosphoramidites have been prepared and attached to the DNA using standard synthesizer chemistry. ${ }^{74}$ Subsequent labelling with different maleimide functionalized labels and optimized reaction conditions as $\mathrm{pH}$, temperature and label concentrations led to complete conjugation with reaction times ranging from $30 \mathrm{~min}$ to several hours for more complex structures as dyes. Also surface immobilization could be achieved by the same group. ${ }^{75}$ Addition of copper(II) nitrate allowed for shorter reaction times less than $1 \mathrm{~h}$ by using a furan moiety at the $5^{\prime}$ end and conjugation of a benzotriazole dye maleimide for attomole detection using surface enhanced resonance Raman scattering (SERRS) ${ }^{76}$ Additionally a furan conjugated to the 5 position of deoxyuridine was reported to act as the diene. ${ }^{77}$ After incorporation into an ODN five commercial available fluorescence dyes were conjugated quantitatively within $3 \mathrm{~h}$ at

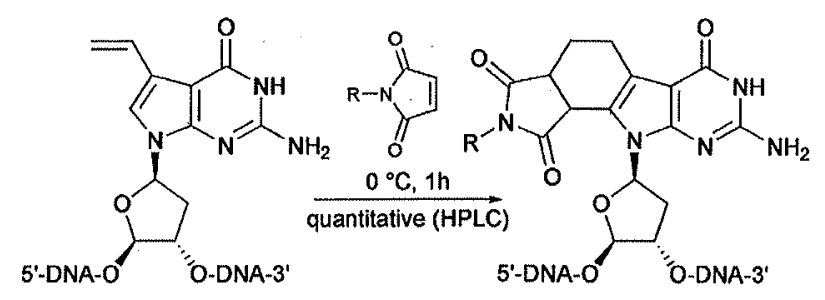

$\mathrm{R}=\mathrm{Me}, \mathrm{CH}_{2} \mathrm{CH}_{2} \mathrm{COOH}$, benzophenon-4-yl, pyrene, TEMPO<smiles>[R]=CCCC(=O)NCCOCCOCCNC(=O)CCCC[C@H]1SC[C@@H]2NC(=O)N[C@@H]21</smiles>

Scheme 2 Diels-Alder reaction using 7-vinyl-7-deaza-2'-deoxyguanosine and different maleinimide labels. ${ }^{72}$

$40^{\circ} \mathrm{C}$ or $4 \mathrm{~h}$ at room temperature. Several other nucleotide analogues using a furan moiety as diene for the incorporation into ODNs have been developed and only sparsely investigated regarding Diels-Alder conjugation efficiency. ${ }^{78}$ As a further example 7-vinyl-7-deaza-2'-deoxyguanosine $3^{\prime}$-phosphoramidite was incorporated into oligonucleotides and subsequent conjugation with different maleimide functionalized labels as carboxylic acid, activated ester, benzophenone, pyrene, TEMPO and biotin was investigated. ${ }^{72}$ Thereby the vinyl double bond and the one in the 5-membered ring of 7-deazaguanine form an electron rich diene, so all labels were attached within $1 \mathrm{~h}$ at $0{ }^{\circ} \mathrm{C}$ in aqueous solution quantitatively with a subsequent $[1,3] \mathrm{H}$-shift restoring the deazaguanine (Scheme 2). These mild conditions are unrivalled, but not further investigated or employed for DNA labelling. Tona and Haner developed a 4 base hairpin mimic containing a 1,3-butadien building block which builds a stable hairpin. ${ }^{79}$ Conjugation using different maleinimides within seven days at $20^{\circ} \mathrm{C}$ resulted in complete conversion retaining the DNA hairpin structure. Later on crosslinking of complementary strands could be achieved using a bismaleinimide and this butadiene building block. ${ }^{80}$ Recently, oligonucleotide-peptide conjugates were prepared using hexadiene $5^{\prime}$ modified oligonucleotides and maleinimide modified peptides. ${ }^{81}$

Over all, the Diels-Alder cycloaddition is a promising reaction for DNA conjugation. The reactive moieties are inert for most biomolecules and can be conjugated under very mild conditions. While only maleinimides are used as dienophile so far, diverse dienes as phosphoramidites have been developed for the incorporation into oligonucleotides. However, all publications reported complete conversion sometimes needing elongated reaction times, which may be overcome by addition of suitable catalysts.

\section{Huisgen $[2+3]$ cycloaddition (click chemistry)}

The small azide group combines high intrinsic reactivity with high chemoselectivity. It reacts for instance with alkynes in a $[2+3]$ dipolar cycloaddition and forms stable triazoles reported first by Huisgen. ${ }^{82}$ Copper catalysis promotes the reaction to proceed at room temperature under aqueous 
conditions using terminal alkynes resulting in defined regiochemistry. ${ }^{83}$ Both azides and alkynes are bioorthogonal and therefore soon recognized for bioconjugation (click chemistry $^{84}$ ) and employed extensively. ${ }^{85}$

For DNA conjugation, the first fluorescein labelling has been reported for the $5^{\prime}$ end of azido labelled ODNs without copper catalysis. ${ }^{86}$ After $72 \mathrm{~h}$ at $80{ }^{\circ} \mathrm{C} 91 \%$ labelled ODN could be isolated. Although copper(I) could damage the DNA, ${ }^{87}$ conditions have been found that allow efficient complete conversion within $2 \mathrm{~h}$ at room temperature without DNA strand breaks. ${ }^{88} \mathrm{~A}$ terminal alkyne has therefore been sequence specifically attached to the DNA using an aziridinebased cofactor mimic for a methyltransferase reaction and smoothly conjugated with three different azide building blocks. ${ }^{88}$ Other examples cover efforts by Carell et al. who developed an octadi(1,7)ynyl 5-substituted $2^{\prime}$-deoxyuridine analogue for incorporation into DNA and observed complete conversion for up to six adjacent alkynes by labelling with an azido carbohydrate, coumarin azide or fluorescein azide. ${ }^{89}$

Seela and Sirivolu further investigated the influence of octadiynyl side chains on thermal stability of DNA duplexes and synthesized therefore also the three missing nucleotide analogues as phosphoramidites. ${ }^{90}$ Incorporation into ODNs showed that each octadiynyl side chain stabilizes the duplex by approximately $2{ }^{\circ} \mathrm{C}$. Further investigation of the effects of the formed triazol moiety located in the DNA major groove revealed that one triazol decreases the duplex stability while consecutive triazoles stack and increase the stability. ${ }^{91}$ In the meantime all diynyl modified nucleotides showed to be good substrates for click chemistry on ODNs. ${ }^{92}$ It is even possible to functionalize ODNs in a modular fashion with different labels due to protecting groups for the alkyne moiety (Scheme 3). ${ }^{93} \mathrm{~A}$ three step labelling has thus been performed using TMS and TIPS protecting groups. Therefore the unprotected alkyne has been labelled first on the solid support after solid phase DNA synthesis. Subsequent deprotection and labelling led to three times labelled ODNs.

Several triphosphates of these nucleotides have been tested in PCR reactions with subsequent click reaction..$^{94}$ Unfortunately, only one nucleotide analogue at the same time could replace its natural counterpart so far. However, the coupling efficiency for the octadiynyl substituted nucleotides was quantitatively for the PCR products as checked by enzymatic digest and HPLC traces.

The click reaction on DNA has yet been used for the generation of gold wires, ${ }^{95}$ DNA-peptide conjugates, ${ }^{96}$ DNA circularization and ligation, ${ }^{97,98}$ perylene dye conjugation, ${ }^{99}$ DNA immobilization on glass slides ${ }^{100}$ and can be accelerated by microwaves. ${ }^{97,101}$ Recently a protocol for detecting DNA synthesis in vivo by click chemistry has been published. ${ }^{102}$ Albeit only available for short time, the click reaction for DNA conjugation has been much investigated and phosphoramidites and triphosphates have been developed for the introduction of alkynes into DNA. The alkyne and triazol moieties do not disturb the DNA duplexes much or even stabilize them and, in principle, complete conversion is achieved for the conjugation within hours at room temperature. The only drawback is the need for the copper ligand catalyst system, which makes the reaction more complicated

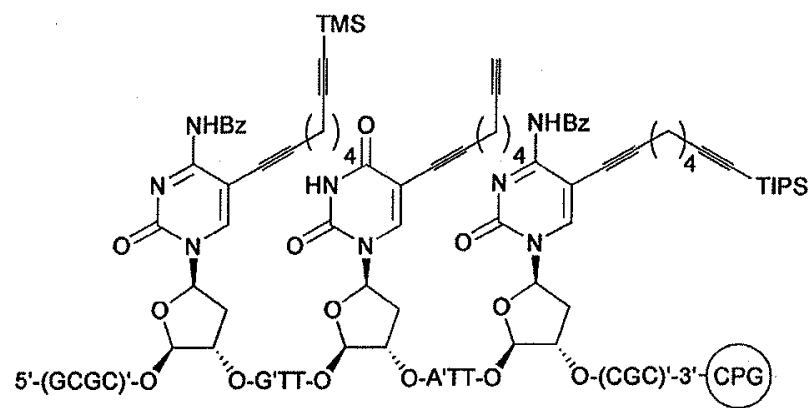

1. Click: CuBr, TBTA, sodium ascorbate, benzyl azide then deprotection of base protecting groups. TMS and cleavage from resin by conc. $\mathrm{NH}_{3}$
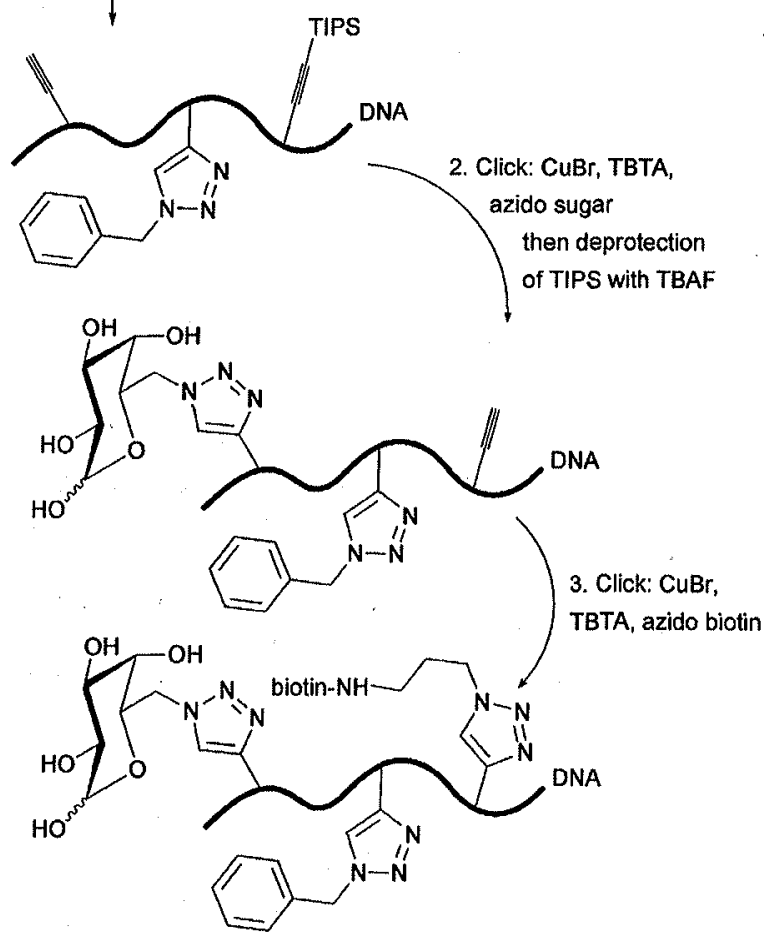

Scheme $33 \times$ click conjugation on DNA. ${ }^{93}$ TMS; trimethylsilyl; TIPS: triisopropylsilyl; CPG: controlled pore glass; TBTA: tris(benzyltriazolyl-methyl)amine; $A^{\prime}, C^{\prime}, G^{\prime}$ : base protected $A, C, G$.

than the other post-synthetic methods. Additionally copper may interfere in subsequent biotransformations that might be required for further DNA-based construction.

\section{Staudinger ligation}

Another ligation reaction utilizing the azide moiety is the Staudinger ligation. Azides react smoothly with triarylphosphines to form iminophosphoranes, which in aqueous phase were hydrolysed to the corresponding amines and triarylphosphinoxid known as Staudinger reduction. ${ }^{104}$ Bertozzi designed a new aryl ligand for the phosphine carrying an ester as electrophilic trap. ${ }^{105}$ This allows the capture of the intermediate aza-ylid before competing hydrolysis can take place, thus conjugating the phosphin with the azide by forming a stable amide bond. Without the requirement of a catalyst this reaction has been used for bioconjugation of peptides, 


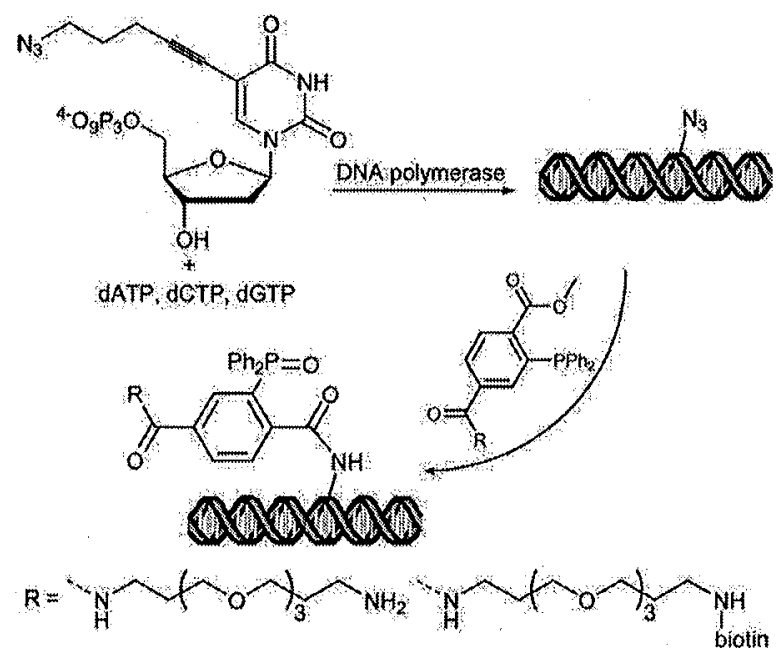

Scheme 4 Azido labelling of DNA with subsequent Staudinger ligation. ${ }^{103}$

carbohydrates and in vivo experiments ${ }^{106}$ as well as for the post-synthetic labelling of DNA.

Fluorescence labelling has been reported conjugating fluorescein with $\sim 90 \%$ yield to the $5^{\prime}$ end of azide modified DNA at room temperature within $12 \mathrm{~h}^{107}$ Comstock and Rajski introduced the azide moiety by methyltransferase dependent sequence specific DNA alkylation using an aziridine-based cofactor mimic based upon 8-azidoadenosine. ${ }^{108}$ Subsequent Staudinger ligation led to complete conjugation of a biotin to the introduced azide within $14 \mathrm{~h}$ and at $40^{\circ} \mathrm{C}$. A more general approach for azide functionalization of DNA was developed by us using 7-deaza-2'-deoxyadenosine and 2'-deoxyuridine triphosphates with alkyl azides linked to the C7 or C5 position, respectively (Scheme 4) ${ }^{103}$ After incorporation into DNA using Pwo DNA polymerase, irrespective of the used linker lengths conjugation of biotin occurred with $70 \%$ conversion without the formation of byproducts.

Although the Staudinger ligation is a promising conjugation reaction, only a few examples for labelling DNA are known so far. The advantages are mild reaction conditions without the need for additional reagents and the high potential for in vivo studies because of truly bioorthogonal reaction partners. Drawbacks are the difficult incorporation of azide or phosphine moiety with phosphoramidite chemistry due to possible oxidation and the synthesis of the phosphine moiety itself.

\section{Methyltranferase directed labelling}

Methyltransferases are enzymes that sequence-specifically methylate DNA. They have been exploited for DNA conjugation recently and allow post-synthetic modification of unmodified DNA. In the native reaction a simple methyl group from the natural substrate S-adenosyl-L-methionine (AdoMet, Scheme 5, 12a) is transferred either to the exocyclic amino group of adenine or cytidine or to $\mathrm{C} 5$ of cytidine depending on the methyltransferase (Scheme 5B). Weinhold et $\mathrm{al}$. developed an $\mathrm{N}$-adenosylaziridine which is accepted by a methyltransferase instead of AdoMet and covalently linked to DNA (Scheme 5, 13a). ${ }^{110}$ Before the methyltransferase
A

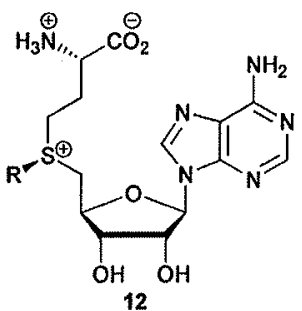<smiles>[R]c1nc2c(N)ncnc2n1[C@H]1O[C@H](CN2CC2)[C@@H](O)[C@@H](O)[C@@H]1CN1CC1</smiles>

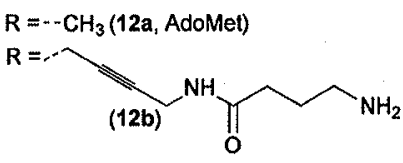
$R^{1}=-H \quad(13 a) R^{1}=-\cdots N_{3}$ (13b) $R^{4}=--\mathrm{NH}-\left(\mathrm{CH}_{2}\right)_{4}-\mathrm{N}_{3}($ (13c) $\mathrm{R}^{4}=--\mathrm{NH}-\left(\mathrm{CH}_{2}\right)_{4}-\mathrm{NH}-$ biotin (13d)

B

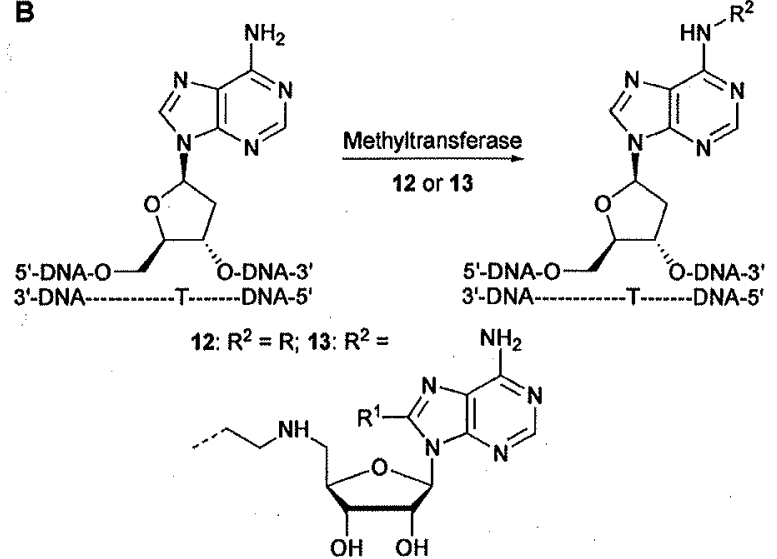

Scheme 5 Labelling by methyltransferases. (A) Natural substrate (12a) and partially labelled analogues (12b, 13a-e). (B) Exemplified methyltransferase reaction. ${ }^{88,108-110}$

reaction the adenosyl moiety has been labelled at $\mathrm{C} 8$ either by biotin or dansyl chloride ${ }^{110}$ or reactive functionalities as azide $^{108}$ and alkyne ${ }^{88}$ for subsequent Staudinger ligation or click chemistry (see respective section) leading to sequencespecific labelled DNA (Scheme 5, 13b-e). Recently Weinhold et al. used AdoMet as lead structure and replaced the S-methyl by a S-propargylic side chain (Scheme $5,12 b) .{ }^{109}$ In this case an amine for subsequent fluorescence labelling was introduced.

\section{Conclusions and outlook}

The manifold applications of labelled DNA afforded efficient approaches for the generation of it. Phosphoramidites are in general readily available or synthesized and allow the chemical synthesis of modified DNA in various fashions of any sequence and relatively large quantities. Hereby the label can be positioned in nearly every direction allowing ODN probes facing minor or major groove. Depending on the label(s) and the modification employed, only shorter ODNs up to 60 nucleotides are feasible but the one step synthesis and ease of purification is a significant advantage. The same holds true for the direct incorporation of labelled triphosphates by DNA polymerases in primer extension reactions or PCR. Here the sequence is given by a template and allows the synthesis and amplification of large multi-labelled DNA strands, which is especially interesting for DNA nano- and material science. For 
the DNA polymerases to accept the modified substrates the label has to be positioned and linked to the base in a specific way either to the $\mathrm{C} 5$ position of pyrimidines or $\mathrm{C} 7$ position of 7-deazapurines. Long linkers even allow bulky labels to be incorporated. Nevertheless the acceptance by a DNA polymerase cannot be predicted for all substrates. Here further systematic investigations may elucidate better structure-activity relationships. Moreover DNA polymerases having a broad substrate spectrum are identified yet, but mutated DNA polymerases can have a much broader substrate spectrum and tailor-made DNA polymerases could broaden the acceptance of modified triphosphates. ${ }^{11}$

Another drawback currently is the triphosphate synthesis which often results in low yields. An advantage is that several functional groups can be tolerated by the DNA polymerases such as hydroxyl, amines and carboxylic acids without protection and the effort of subsequent deprotection after the enzymatic reactions.

In cases where the label disturbs incorporation either by phosphoramidite chemistry or enzymatic reaction, the postsynthetic approach reveals its power. By introducing a reactive function which is well accepted by chemical DNA synthesis or polymerases the label itself is added in a subsequent reaction after ODN synthesis. Moreover this allows flexible conjugation of different labels to the same ODN. As a standard method this has been widely used by introducing amines which can be coupled with electrophiles. Incomplete conjugation at mild reaction conditions was the main problem apart from the elaborate two-step approach with two purifications. The extension of bioorthogonal reactions to DNA allows the attachment of complicated labels as well as conjugation in water with high yields. Here the click reaction is best investigated and shows high conjugation efficiency even for multi-labelled PCR products at mild reaction conditions. Complementary reactions are Diels-Alder cycloaddition based upon double bounds and Staudinger ligation using phosphines and azides in spite of alkynes and azides for the click reaction. One current advantage of the Diels-Alder reaction is that maleimides can be used as functionalities where suitable building blocks are commercially available.

With these new methods it should be possible to attach in principle any label to the DNA. Thus, promising applications in nano- and material science wait for their development.

\section{Notes and references}

1 A. Condon, Nat. Rev. Genet., 2006, 7, 565-575.

2 (a) N. C. Seeman, Mol. Biotechnol., 2007, 37, 246-257; (b) U. Feldkamp and C. M. Niemeyer, Angew. Chem., Int. Ed., 2006, 45, 1856-1876; (c) P. W. K. Rothemund, Nature, 2006, 440, 297-302.

3 M. Strerath and A. Marx, Angew. Chem., Int. Ed., 2005, 44, $7842-7849$.

4 (a) Z. J. Gartner, R. Grubina, C. T. Calderone and D. R. Liu, Angew. Chem., Int. Ed., 2003, 42, 1370-1375; (b) D. Summerer and A. Marx, Angew. Chemt, Int. Ed., 2002, 41, 89-90; (c) Z. J. Gartner and D. R. Liu, J. Am. Chem. Soc., 2001, 123, 6961-6963.

5 Q. Gu, C. Cheng, R. Gonela, S. Suryanarayanan, S. Anabathula, K. Dai and D. T. Haynie, Nanotechnology, 2006, 17, R14-R25.

6 K. Keren, M. Krueger, R. Gilad, G. Ben-Yoseph, U. Sivan and E. Braun, Science, 2002, 297, 72-75.
7 (a) J. M. Kinsella and A. Ivanisevic, Langmuir, 2007, 23, 3886-3890; (b) Q. Gu, C. Cheng, S. Suryanarayanan, K. Dai and D. T. Haynie, Physica E, 2006, 33, 92-98.

8 M. Heilemann, R. Kasper, P. Tinnefeld and M. Sauer, J. Am. Chem. Soc., 2006, 128, 16864-16875.

9 C. M. Niemeyer, Chem.-Eur. J., 2001, 7, 3188-3195.

10 (a) U. Asseline, Curr. Org. Chem., 2006, 10, 491-518; (b) R. T. Ranasinghe and T. Brown, Chem. Commun., 2005, 5487-5502.

11 T. S. Zatsepin and T. S. Oretskaya, Chem. Biodiversity, 2004, 1, 1401-1417.

12 E. M. Southern, Methods Mol. Biol. (Totowa, NJ, U. S.), 2001, 170, 1-15.

13 (a) Y. Huang and J. M. Coull, J. Am. Chem. Soc., 2008, 130, 3238-3239; (b) M. W. Kanan, M. M. Rozenman, K. Sakurai, T. M. Snyder and D. R. Liu, Nature, 2004, 431, 545-549; (c) D. Y. Zhang, A. J. Turberfield, B. Yurke and E. Winfree, Science, 2007, 318, 1121-1125; (d) Z. Tang and A. Marx, Angew. Chem., Int Ed., 2007, 46, 7297-7300.

14 R. Ting, J. M. Thomas, L. Lermer and D. M. Perrin, Nucleic Acids Res., 2004, 32, 6660-6672.

15 S. Jäger, G. Rasched, H. Kornreich-Leshem, M. Engeser, O. Thum and M. Famulok, J. Am. Chem. Soc., 2005, 127 15071-15082.

16 S. L. Beaucage, Compr. Nat. Prod. Chem., 1999, 7, 153-249.

17 (a) A. J. A. Cobb; Org. Biomol. Chem., 2007, 5, 3260-3275; (b) N Venkatesan, K. Su Jeong and K. Byeang Hyean, Curr. Med. Chem., 2003, 10, 1973-1991.

18 (a) S. M. Waybright, C. P. Singleton, K. Wachter, C. J. Murphy and U. H. F. Bunz, J. Am. Chem. Soc., 2001, 123, 1828-1833; (b) T. L. Sheppard, C.-H. Wong and G. F. Joyce, Angew. Chem., Int $E d ., 2000,39,3660-3663$.

19 P. Grünefeld and C. Richert, J. Org. Chem., 2004, 69, 7543-7551.

20 P. Ćapek, H. Cahová, R. Pohl, M. Hocek, C. Gloeckner and A. Marx, Chem.-Eur. J., 2007, 13, 6196-6203.

21 G. F. Kaufmann, M. M. Meijler, C. Sun, D.-W. Chen, D. P. Kujawa, J. M. Mee, T. Z. Hoffman, P. Wirsching, R. A. Lerner and K. D. Janda, Angew. Chem., Int. Ed., 2005, 44, 2144-2148.

22 F. Seela and M. Zulauf, Chem.-Eur. J., 1998, 4, 1781-1790.

23 (a) M. Adamczyk, C. M. Chan, J. R. Fino and P. G. Mattingly, $J$ Org. Chem., 2000, 65, 596-601; (b) M. V. Kvach, D. A. Tsybulsky, A. V. Ustinov, I. A. Stepanova, S. L. Bondarev, S. V. Gontarev, V. A. Korshun and V. V. Shmanai, Bioconjugate Chem., 2007, 18, $1691-1696$

24 M. H. Lyttle, T. G. Carter, D. J. Dick and R. M. Cook, J. Org. Chem., 2000, 65, 9033-9038.

25 M. V. Kvach, A. V. Ustinov, I. A. Stepanova, A. D. Malakhov, M. V. Skorobogatyi, V. V. Shmanai and V. A. Korshun, Eur. $J$. Org. Chem., 2008, 2008, 2107-2117.

26 K. R. Birikh, V. A. Korshun, P. L. Bernad, A. D. Malakhov, N. Milner, S. Khan, E. M. Southern and M. S. Shchepinov, Anal. Chem., 2008, 80, 2342-2350.

27 G. Goel, A. Kumar, A. K. Puniya, W. Chen and K. Singh, $J$ Appl. Microbiol., 2005, 99, 435-442.

28 (a) K. Yamana, H. Zako, K. Asazuma, R. Iwase, H. Nakano and A. Murakami, Angew. Chem., Int. Ed., 2001, 40, 1104-1106; (b) M. Nakamura, Y. Fukunaga, K. Sasa, Y. Ohtoshi, K. Kanaori, H. Hayashi, H. Nakano and K. Yamana, Nucleic Acids Res., $2005,33,5887-5895$.

29 (a) M. Nakamura, Y. Murakami, K. Sasa, H. Hayashi and K. Yamana, J. Am. Chem. Soc., 2008, 130, 6904-6905; (b) A. Mahara, R. Iwase, T. Sakamoto, K. Yamana, T. Yamaoka and A. Murakami, Angew. Chem., Int. Ed., 2002, 41, 3648-3650.

30 V. A. Korshun, D. A. Stetsenko and M. J. Gait, J. Chem. Soc., Perkin Trans. 1, 2002, 1092-1104.

31 A. Misra, S. Mishra and K. Misra, Bioconjugate Chem., 2004, 15, 638-646.

32 N. N. Dioubankova, A. D. Malakhov, Z. O. Shenkarev and V. A. Korshun, Tetrahedron, 2004, 60, 4617-4626.

33 (a) I. V. Astakhova, A. D. Malakhov, I. A. Stepanova, A. V. Ustinov, S. L. Bondarev, A. S. Paramonov and V. A. Korshun, Bioconjugate Chem., 2007, 18, 1972-1980; (b) N. N. Dioubankova, A. D. Malakhov, D. A. Stetsenko, M. J. Gait, P. E. Volynsky, R. G. Efremov and V. A. Korshun, ChemBioChem, 2003, 4, 841-847.

34 C. Richert and P. Grünefeld, Synlett, 2007, 1-18. 
35 (a) M. Printz and C. Richert, J. Comb. Chem., 2007, 9, 306-320; (b) K. Kawai, K. Kawabata, S. Tojo and T. Majima, Bioorg. Med. Chem. Lett., 2002, 12, 2363-2366; (c) K. Kawai, H. Yoshida, T. Takada, S. Tojo and T. Majima, J. Phys. Chem, B, 2004, 108, 13547-13550.

36 S. Sitaula and S. M. Reed, Bioorg. Med. Chem. Lett., 2008, 18, $850-855$.

37 (a) S. K. Singh, P. Nielsen, A. A. Koshkina and J. Wengel, Chem Commun., 1998, 455-456; (b) A. A. Koshkin, S. K. Singh, P. Nielsen, V. K. Rajwanshi, R. Kumar, M. Meldgaard, C. E. Olsen and J. Wengel, Tetrahedron, 1998, 54, 3607-3630.

38 N. Kalra, M. C. Parlato, V. S. Parmar and J. Wengel, Bioorg. Med. Chem. Lett., 2006, 16, 3166-3169.

39 (a) M. D. Sørensen, M. Petersen and J. Wengel, Chem. Commun., 2003, 2130-2131; (b) D. Lindegaard, A. S. Madsen, I. V. Astakhova, A. D. Malakhov, B. R. Babu, V. A. Korshun and J. Wengel, Bioorg. Med. Chem., 2008, 16, 94-99; (c) P. J. Hrdlicka, B. R. Babu, M. D Sorensen and I. Wengel, Chem. Commun., 2004, 1478-1479; (d) D. Honcharenko, C. Zhou and J. Chattopadhyaya, J. Org. Chem., 2008, 73, 2829-2842.

40 (a) J. Hunziker, Bioorg. Med. Chem. Lett., 1999, 9, 201-204 (b) K. Matsuura, M. Hibino, T. Ikeda, Y. Yamada and K. Kobayashi, Chem.-Eur. J., 2004, 10, 352-359.

41 (a) T. A. Walton, M. H. Lyttle, D. J. Dick and R. M. Cook Bioconjugate Chem., 2002, 13, 1155-1158; (b) M. V. Skorobogatyi, A. D. Malakhov, A. A. Pchelintseva, A. A. Turban, S. L. Bondarev and V. A. Korshun, ChemBio Chem, 2006, 7, 810-816; (c) L. Clima and W. Bannwarth, Helv. Chim. Acta, 2008, 91, 165-175; (d) K. Tainaka, K. Tanaka, S. Ikeda, K. i. Nishiza, T. Unzai, Y. Fujiwara, I. Saito and A. Okamoto, J. Am. Chem. Soc., 2007 $129,4776-4784$

42 L. A. Fendt, I. Bouamaied, S. Thoni, N. Amiot and E. Stulz, $J$. Am. Chem. Soc., 2007, 129, 15319-15329.

43 J. D. Kahl, D. L. McMinn and M. M. Greenberg, J. Org. Chem. $1998,63,4870-4871$

44 (a) J. T. Hwang and M. M. Greenberg, Org. Lett., 1999, 1, 2021-2024; (b) J. D. Kahl and M. M. Greenberg, J. Am. Chem. Soc., 1999, 121, 597-604.

45 K. Shinozuka, S. Kohgo, H. Ozaki and H. Sawai, Chem Commun., 2000, 59-60.

46 S. I. Khan and M. W. Grinstaff, J. Am. Chem. Soc., 1999, 121, 4704-4705.

47 (a) M. Rist, N. Amann and H.-A. Wagenknecht, Eur. J. Org. Chem., 2003, 2498-2504; (b) E. Mayer, L. Valis, C. Wagner, M. Rist, N. Amann and H.-A. Wagenknecht, ChemBioChem, 2004, 5, 865-868.

48 (a) O. Schiemann, N. Piton, Y. Mu, G. Stock, J. W. Engels and T. F. Prisner, J. Am. Chem. Soc., 2004, 126, 5722-5729; (b) S. Obeid M. Yulikov, G. Jeschke and A. Marx, Angew. Chem., Int. Ed. $2008,47,6782-6785$.

49 T. Kottysch, C. Ahlborn, F. Brotzel and C. Richert, Chem.-Eur. $J ., 2004,10,4017-4028$.

50 A. Fegan, P. S. Shirude and S. Balasubramanian, Chem. Commun., 2008, 2004-2006.

51 X. Wu and S. Pitsch, Helv. Chim. Acta, 2000, 83, 1127-1144.

52 D. M. Perrin, T. Garestier and C. Hélène, J. Am. Chem. Soc., $2001,123,1556-1563$.

$53(a)$ L. H. Thoresen, G.-S. Jiao, W. C. Haaland, M. L. Metzker and K. Burgess, Chem.-Eur. J., 2003, 9, 4603-4610; (b) K. J Livak, F. W. Hobbs and R. Zagursky, Nucleic Acids Res., 1992 20, 4831-4837; (c) M. A. Augustin, W. Ankenbauer and B. Angerer, J. Biotechnol., 2001, 86, 289-301; $(d)$ G. Giller, T. Tasara, B. Angerer, K. Muhlegger, M. Amacker and H. Winter, Nucleic Acids Res., 2003, 31, 2630-2635; (e) T. Tasara, B. Angerer, M. Damond, H. Winter, S. Dorhofer, U. Hübscher and M. Amacker, Nucleic Acids Res., 2003, 31, 2636-2646.

54 A. Ortiz and E. Ritter, Nucleic Acids Res., 1996, 24, 3280-3281.

55 K. Sakthivel and C. F. Barbas, III, Angew. Chem., Int. Ed., 1998, 37, 2872-2875.

56 M. Kuwahara, J.-I. Nagashima, M. Hasegawa, T. Tamura, R. Kitagata, K. Hanawa, S.-I. Hososhima, T. Kasamatsu, H. Ozaki and H. Sawai, Nucleic Acids Res., 2006, 34, 5383-5394.

57 T. Gourlain, A. Sidorov, N. Mignet, S. J. Thorpe, S. E. Lee, J. A. Grasby and D. M. Williams, Nucleic Acids Res., 2001, 29, 1898-1905.
58 T. Ohbayashi, M. Kuwahara, M. Hasegawa, T. Kasamatsu, T. Tamura and H. Sawai, Org. Biomol. Chem., 2005, 3, 2463-2468.

59 M. Kuwahara, K. Hanawa, K. Ohsawa, R. Kitagata, H. Ozaki and H. Sawai, Bioorg. Med. Chem., 2006, 14, 2518-2526.

60 M. Matsui, Y. Nishiyama, S. Ueji and Y. Ebara, Bioorg. Med. Chem. Lett, 2007, 17, 456-460.

61 A. Shoji, T. Hasegawa, M. Kuwahara, H. Ozaki and H. Sawai, Bioorg. Med. Chem. Lett., 2007, 17, 776-779.

62 S. Jäger and M. Famulok, Angew. Chem., Int. Ed., 2004, 43, 3337-3340.

63 V. Roig and U. Asseline, J. Am. Chem. Soc., 2003, 125, $4416-4417$.

64 D. S. Jones, P. A. Barstad, M. J. Feild, J. P. Hachmann, M. S. Hayag, K. W. Hill, G. M. Iverson, D. A. Livingston and M. S. Palanki, et al., J. Med. Chem., 1995, 38, 2138-2144.

65 S. S. Ghosh, P. M. Kao, A. W. McCue and H. L. Chappelle, Bioconjugate Chem., 1990, 1, 71-76.

66 S. B. Rajur, C. M. Roth, J. R. Morgan and M. L. Yarmush, Bioconjugate Chem., 1997, 8, 935-940.

67 B. Bornemann, S.-P. Liu, A. Erbe, E. Scheer and A. Marx, ChemPhysChem, 2008, 9, 1241-1244.

68 M. M. Masud, A. Ozaki-Nakamura, M. Kuwahara, H. Ozaki and H. Sawai, ChemBioChem, 2003, 4, 584-588.

69 O. Diels and K. Alder, Justus Liebigs Ann. Chem., 1928, 460, 98-122.

70 (a) D. C. Rideout and R. Breslow, J. Am. Chem. Soc., 1980, 102, 7816-7817; (b) S. Otto, F. Bertoncin and J. B. F. N. Engberts, J. Am. Chem. Soc., 1996, 118, 7702--7707.

71 D. Graham and A. Enright, Curr. Org. Synth., 2006, 3, 9-17.

72 A. Okamoto, T. Taiji, K. Tainaka and I. Saito, Bioorg. Med. Chem. Lett., 2002, 12, 1895-1896.

73 B. Seelig and A. Jäschke, Chem. Biol., 1999, 6, 167-176; T. M. Tarasow, S. L. Tarasow and B. E. Eaton, Nature, 1997, 389, 54-57.

74 K. W. Hill, J. Taunton-Rigby, J. D. Carter, E. Kropp, K. Vagle, W. Pieken, D. P. McGee, G. M. Husar, M. Leuck, D. J. Anziano and D. P. Sebesta, J. Org. Chem., 2001, 66, 5352-5358.

75 (a) G. M. Husar, D. J. Anziano, M. Leuck and D. P. Sebesta, Nucleosides, Nucleotides Nucleic Acids, 2001, 20, 559-566; (b) $\mathrm{H}$. A. Latham-Timmons, A. Wolter, J. S. Roach, R. Giare and M. Leuck, Nucleosides, Nucleotides Nucleic Acids, 2003, 22 1495-1497.

76 (a) L. Fruk, A. Grondin, W. E. Smith and D. Graham, Chem. Commun., 2002, 2100-2101; (b) D. Graham, L. Fruk and W. E Smith, Analyst, 2003, 128, 692-699.

77 D. Graham, A. Grondin, C. McHugh, L. Fruk and W. E. Smith, Tetrahedron Lett., 2002, 43, 4785-4788.

78 (a) K. Stevens and A. Madder, Nucleosides, Nucleotides Nucleic Acids, 2007, 26, 1359-1362; (b) E. Anderson and D. Picken, Nucleosides, Nucleotides Nucleic Acids, 2005, 24, 761-765.

79 R. Tona and R. Haner, Chem. Commun., 2004, 1908-1909; R. Tona and R. Haner, Bioconjugate Chem., 2005, 16, 837-842.

80 R. Tona and R. Haner, Mol. BioSyst., 2005, 1, 93-98.

81 V. Marchan, S. Ortega, D. Pulido, E. Pedroso and A. Grandas, Nucleic Acids Res., 2006, 34, e24.

82 R. Huisgen, Angew. Chem., Int. Ed. Engl., 1963, 2, 565-598.

83 (a) V. V. Rostovtsev, L. G. Green, V. V. Fokin and K. B Sharpless, Angew. Chem., Int. Ed., 2002, 41, 2596-2599; (b) C W. Tornoe, C. Christensen and M. Meldal, J. Org. Chem., 2002, 67, 3057-3064

84 H. C. Kolb, M. G. Finn and K. B. Sharpless, Angew. Chem., Int. $E d ., 2001,40,2004-2021$.

85 (a) J. E. Moses and A. D. Moorhouse, Chem. Soc. Rev., 2007, 36 1249-1262; (b) R. Breinbauer and M. Köhn, ChemBioChem, 2003, 4, 1147-1149.

86 T. S. Seo, Z. Li, H. Ruparel and J. Ju, J. Org. Chem., 2003, 68, $609-612$.

87 C. J. Burrows and J. G. Muller, Chem. Rev., 1998, 98, 1109-1152.

88 R. L. Weller and S. R. Rajski, Org. Lett., 2005, 7, 2141-2144.

89 J. Gierlich, G. A. Burley, P. M. Gramlich, D. M. Hammond and T. Carell, Org. Lett., 2006, 8, 3639-3642.

90 F. Seela and V. R. Sirivolu, Chem. Biodiversity, 2006, 3, 509-514.

91 P. Kocalka, N. K. Andersen, F. Jensen and P. Nielsen, ChemBioChem, 2007, 8, 2106-2116. 
92 F. Seela, V. R. Sirivolu and P. Chittepu, Bioconjugate Chem., $2008,19,211-224$.

93 P. M. Gramlich, S. Warncke, J. Gierlich and T. Carell, Angew. Chem., Int. Ed., 2008, 47, 3442-3444.

94 P. M. Gramlich, C. T. Wirges, J. Gierlich and T. Carell, Org. Lett., 2008, 10, 249-251.

95 (a) M. Fischler, A. Sologubenko, J. Mayer, G. Clever, G. Burley, J. Gierlich, T. Carell and U. Simon, Chem. Commun., 2008, 169-171; (b) M. Fischler, U. Simon, H. Nir, Y. Eichen, G. A. Burley, J. Gierlich, P. M. Gramlich and T. Carell, Small, 2007, 3, 1049-1055.

96 K. Gogoi, M. V. Mane, S. S. Kunte and V. A. Kumar, Nucleic Acids Res., 2007, 35, el39.

97 J. Lietard, A. Meyer, J. J. Vasseur and F. Morvan, J. Org. Chem., $2008,73,191-200$.

98 (a) R. Kumar, A. El-Sagheer, J. Tumpane, P. Lincoln, L. M. Wilhelmsson and T. Brown, J. Am. Chem. Soc., 2007, 129, 6859-6864; (b) M. Nakane, S. Ichikawa and A. Matsuda, $J$. Org. Chem., 2008, 73, 1842-1851.

99 A. V. Ustinov, V. V. Dubnyakova and V. A. Korshun, Tetrahedron, 2008, 64, 1467-1473.

100 D. I. Rozkiewicz, J. Gierlich, G. A. Burley, K. Gutsmiedl, T. Carell, B. J. Ravoo and D. N. Reinhoudt, ChemBioChem, 2007, 8, 1997-2002.

101 I. Geci, V. V. Filichev and E. B. Pedersen, Chem.-Eur. J., 2007, $13,6379-6386$.
102 S. Adrian and J. M. Timothy, Proc. Natl. Acad. Sci. U. S. A., 2008, 105, 2415-2420.

103 (a) S. H. Weisbrod and A. Marx, Chem. Commun., 2007, 1828-1830; (b) A. Baccaro, S. H. Weisbrod and A. Marx, Synthesis, 2007, 1949-1954.

104 H. Staudinger and J. Meyer, Helv. Chim. Acta, 1919, 2, 635-646.

105 E. Saxon and C. R. Bertozzi, Science, 2000, 287, 2007-2010.

106 M. Köhn and R. Breinbauer, Angew. Chem., Int. Ed., 2004, 43, 3106-3116.

107 C. C. Wang, T. S. Seo, Z. Li, H. Ruparel and J. Ju, Bioconjugate Chem., 2003, 14, 697-701.

108 (a) L. R. Comstock and S. R. Rajski, Nucleic Acids Res., 2005, 33, 1644 1652; (b) L. R. Comstock and S. R. Rajski, J. Am. Chem. Soc., 2005, 127, 14136-14137.

109 G. Lukinavičius, V. Lapienè, Z. Staševskij, C. Dalhoff, E. Weinhold and S. Klimašauskas, J. Am. Chem. Soc., 2007, 129, 2758-2759.

110 G. Pljevaljčić, F. Schmidt and E. Weinhold, ChemBioChem, 2004, $5,265-269$.

111 (a) A. M. Leconte, L. Chen and F. E. Romesberg, J. Am. Chem. Soc., 2005, 127, 12470-12471; (b) M. Fa, A. Radeghieri, A. A. Henry and F. E. Romesberg, $J$. Am. Chem. Soc., 2004, 126, 1748-1754; (c) C. Gloeckner, K. B. Sauter and A. Marx, Angew. Chem., Int. Ed., 2007, 46, 3115-3117. 